\title{
新ベッセル型機械的粒子複合化装置の特性評価
}

\section{Particle Composite Process by A New Vessel Type Mixer}

\author{
堀田 禎 ${ }^{\mathrm{a}}$, 福井武久 ${ }^{\mathrm{a}}$, 大川 元 $^{\mathrm{a}}$, 大原 智 ${ }^{\mathrm{a}}$, 内藤 牧男 ${ }^{\mathrm{a}}$, \\ Tadashi Hotta, Takehisa Fukui, Hajime Okawa, Satoshi Ohara, Makio Naito, \\ 朝日 正三 ${ }^{b}$, 遠藤 茂寿 ${ }^{c}$, 野城 清 $^{\mathrm{d}}$ \\ Shozo Asahi, Shigehisa Endoh, Kiyoshi Nogi
}

Received 25 December; Accepted 20 February 2001

Composite process by the deposition of fine particles onto surfaces of core particles with a new vessel type mixer has been analyzed. In this paper, a new apparatus based on a high-speed ellipticalrotor-type mixer is proposed. The effects of rotor revolution and processing time on the composite process were investigated, and the composite particles for fuel cell electrodes such as MCFC and SOFC were fabricated. As a result, the mass fraction of fine particles strongly fixed on the core particle surface increased with the rotor revolution and the processing time below the critical revolution. Adding small portion of fine particles repeatedly to the powder was effective to achieve a higher mass fraction of fine particles on the core particle surface.

Filament-shaped $\mathrm{Ni}$ particles were successfully covered with fine $\mathrm{CoO}$ particles, and $\mathrm{NiO}$ sphere particles were also uniformly covered with fine YSZ particles by making use of the apparatus.

Key Words : Composite process, Composite particle, Mixer, Electrode, Fuel cell

\section{1. 緒 言}

乾式機械的方法により粒子を異種微粒子などと複合 化する試み"1 は, 電池分野 ${ }^{2)}$ をはじめとして様々の分 野で活発に展開されている。これに対応して，複合化 プロセスに関する研究も進められており，粒子表面へ の微粒子複合化に対しては, 摩砕式粉砕機を応用した 方法 ${ }^{3.4)}$ や高速気流中衝撃法年 5)，さらには高速楕円 ロータ一型混合機6 8) などにおいて，それぞれ解析が

$\mathrm{a}($ 財)ファインセラミックスセンター試験研究所

（テ456-8587 名古屋市熱田区六野 2-4-1）TEL 052-871-3500

Japan Fine Ceramics Center

(2-4-1. Mutsuno, Atuta-ku, Nagoya-shi 456-8587)

b (株)徳寿工作所

（宁254-0074 平塚市大原 3-19） TEL 0463-32-1840

Tokuju Corporation

(3-19, Ohara, Hiratsuka-shi 254-0074)

c 工業技術院資源環境技術総合研究所

（テ305-0053 つくば市小野川16-3） TEL 0298-61-8465

National Institute for Resources and Environment

(16-3, Onogawa, Tsukuba-shi 305-0053)

d 大阪大学接合科学研究所

（宁567-0047 茨木市美穗ヶ丘11-1）TEL 066-879-8643

Joining and Welding Research Institute, Osaka University

(11-1, Mihogaoka, Ibaraki-shi 567-0047)
進められている。

そこで筆者らは，この機械的手法による粒子複合化 技術により, 溶融炭酸塩型燃料電池 $(\mathrm{MCFC})$ 用力 ソード電極のミクロ構造を制御する研究を進めてき た。その結果, 球状 $\mathrm{Ni}$ 粒子表面に $\mathrm{CoO}$ 微粒子を固 定化した複合粒子を出発原料として用いることによ り, $\mathrm{NiO}$ 表面に $\mathrm{Li}(\mathrm{Co}, \mathrm{Ni})$ 酸化物層を生成させた微 構造を電極中に作製することに成功し, 従来の $\mathrm{NiO}$ から成る電極に比へて溶融炭酸塩中での耐食性に優れ たカソード電極を作製可能であることを実験的に明ら かにした ${ }^{9)}$ 。

しかしながら, 燃料電池用電極を初めとして, 今後 電池分野におけるこの技術の適用を促進するために は，これら出発原料となる複合粒子を高品質かつ低コ ストにて製造することが不可欠である。そこで筆者ら は，上記複合化技術の中で高速楕円ローター型混合機 をべースとして, 電池分野への応用を目指した新装置 開発の検討を進めてきた。この混合機は，既に粒子混 合性に優れていることが報告されている ${ }^{6)}$ が，その構 造はFig. 1 (a) に見るように, 混合容器が回転すると ともに，その中の棈円ローターも高速回転するという 


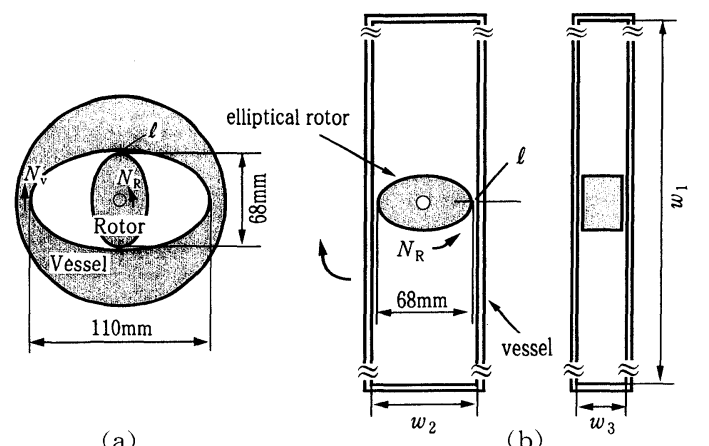

(b)

Fig. 1 Mechanical principles of composite apparatus, (a) existing type, (b) new type

複雑なものである。従って, 電池材料において必要と されるように, 容器中の処理雲囲気を変えたり, 処理 時に容器中に微量ずつ粉体を添加するような複合化操 作は極めて困難である。さらに，生産規模に応じて将 来的に装置のスケールアップを図る場合，一度に大量 の粉体を 1 バッチで処理することが必要になるが，そ の際には高速回転する棈円ローターのサイズや回転容 器のサイズを必然的に大きくしなくてはならないなど の問題が生じてくる。

そこで本報では，この装置の基本構造は活かしつ つ，上記課題に対応可能な機械的原理を持つ複合化装 置を考案するとともに，その第 1 ステップとして粒子 複合化装置としての基本特性の検討を行った。さら に, 電池分野への応用の可能性を探るために, 一例と して燃料電池電極用複合微粒子を作製し，そのミクロ 構造の観察を行うことにより, 本装置の適用可能性を 検討した。

\section{2. 実 験}

Fig. 1（b）に, 今回試作した装置の基本構造を示 す。この装置は，Fig. 1 (a) の棈円ローターに見る従 来型装置の基本構造は残しているものの，その上下に 任意の形状, サイズの容器を有している。そして, 粉 体処理の際には, 回転ローターは高速回転するもの の, この容器は Fig. 2 にモデ的に示すように低速に て繰り返し傾斜することにより, ローターと容器内壁 間の複合化領域に粉体を供給することになる。その結 果, 複合化領域においては粉体の繰り返し複合化処理 が行われる。この機械的原理により, 容器の運動は従 来型に比へて格段に緩慢になるため, 運転中に容器の 䨌囲気を変換したり, 容器中に異種粉体を添加する操 作も容易になる。さらに，1 バッチ処理量を増やした
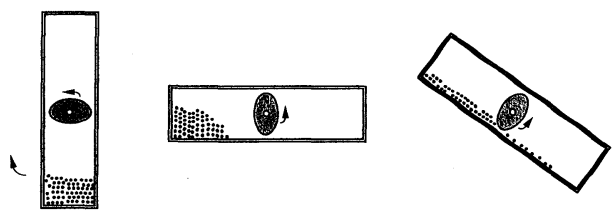

Fig. 2 Powder motion in the new type mixer

Table 1 Conditions for basic experiments

\begin{tabular}{l|c}
\hline Vessel size & $\begin{array}{c}w_{1}=540 \mathrm{~mm}, w_{2}=70 \mathrm{~mm}, \\
w_{3}=32 \mathrm{~mm}\end{array}$ \\
\hline Vessel volume & $1200 \mathrm{~cm}^{3}$ \\
\hline Core particle & $\begin{array}{c}\text { Soda- lime glass beads } \\
d_{\mathrm{c}}=165 \mu \mathrm{m}^{*} \\
\rho_{\mathrm{c}}=2.5 \times 10^{3} \mathrm{~kg} / \mathrm{m}^{3}\end{array}$ \\
\hline Fine powder & $\begin{array}{c}\text { Titanium dioxide } \\
d_{\mathrm{f}}=0.015 \mu \mathrm{m} \\
\rho_{\mathrm{f}}=4.3 \times 10^{3} \mathrm{~kg} / \mathrm{m}^{3}\end{array}$ \\
\hline Content of fine powder & $3 \mathrm{mass} \%$ \\
\hline Length of $\ell$ & $1 \mathrm{~mm}$ \\
\hline Rev. of rotor $\left(N_{\mathrm{R}}\right)$ & $1000 \sim 5000 \mathrm{rpm}$ \\
\hline
\end{tabular}

${ }^{*}$ measured with sieve

い場合, 容器の容量を増加させることにより棈円ロー ターのサイズを極度に大きくすることが不要になるた め, 将来的なスケールアップなどにも対応可能な構造 であると考えられる。

実験は，まず粒子複合化の基本特性として，核粒子 表面への微粒子複合化過程のモデル粒子を使用した検 討を行った。実験に使用したベッセルサイズ，容量並 びに粉体と複合化操作条件を Table 1 に示す。ここで は，まず，最も複合化に影響すると予測される楕円 ローターの回転数と処理時間に着目 ${ }^{7)} し$ ここれらの核 粒子表面への微粒子複合化に及ぼす影響を検討した。 ここで，核粒子 $145.5 \mathrm{~g}$ と微粒子 $4.5 \mathrm{~g}$ を粉体供給部 に投入し，供給部は一定時間毎に半回転するように設 定した。なお, 粉体の容器に占める充填率は, 約 $8 \%$ であった。また複合化実験は, 所定のロータ一回転数 にて行った。さらに，ここでは，この複合化装置の機 能を生かして, 微粒子を粉体処理中に繰り返し微量添 加する複合化処理実験も実施し，複合化過程の検討を 行った。得られた粉体の複合化特性評価として,ここ では既報7. 8) と同様に，核粒子表面における微粒子の 複合化状態を SEM にて観察するとともに, 液中の超 音波照射によっても剥離しない程度に核粒子表面に固 定化された微粒子の付着率を測定した。ここで，その 
Table 2 Powder materials used to make composite particles for fuel cell electrodes

\begin{tabular}{l|c|c|c|c|c}
\hline \multirow{2}{*}{ Purpose } & \multicolumn{2}{|c|}{ Core particle } & \multicolumn{2}{c|}{ Fine particles } & \multicolumn{2}{c}{$\begin{array}{c}\text { Mass fraction } \\
\text { of fine particles }\end{array}$} \\
\hline Cathode for MCFC & Material & Average diameter & Material & Average diameter & Ni \\
\hline Anode for SOFC & $\mathrm{NiO}$ & $3 \mu \mathrm{m}$ & $\mathrm{CoO}$ & $0.3 \mu \mathrm{m}$ & $5 \mathrm{mass} \%$ \\
\hline
\end{tabular}

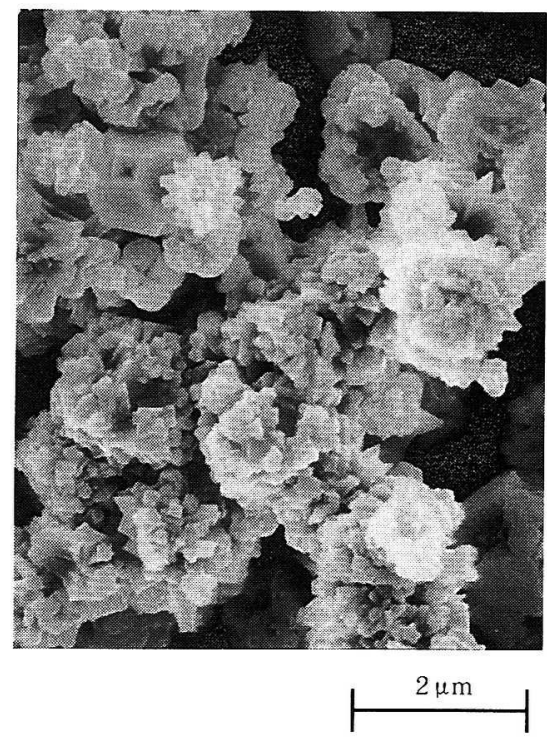

Fig. 3 SEM photograph of filament shaped $\mathrm{Ni}$ particles

測定方法は, 処理品をエタノール中にて, 超音波ホモ ジナイザー（(株)日本精機製作所製, Model US300）を用いて出力 $300 W$ で 1 分間分散処理を行っ た。その後, この分散処理品を目開き $45 \mu \mathrm{m}$ のふる いを用いてエタノールで洗浄しながらふるい分けを行 い, 核粒子両面に固定化されていない微粒子を洗い流 した。そして，ふるい上に残ったサンプルを乾燥機で 一昼夜乾燥後, その質量を求めた。これらを基に, 超 音波によっても剥離しない程度に強く固定されている 二酸化チタンのガラスビーズ表面への付着率 $n_{\mathrm{f}}$ を, ガラスビーズ単位質量当たりの二酸化チタン質量とし て算出した。

また, 燃料電池電極用複合微粒子作製への応用とし て, 本報では Table 2 に示すように 2 種類の複合粒子 を取り上げ，それぞれ複合化実験を行った。特に実験 に用いた Ni 粒子は，Fig. 3に見るようにフィラメン ト状の構造をしており， MCFC 用カソード電極とし て応用するためには，その形状を保持したまま $\mathrm{CoO}$ 微粒子を複合化することが必要である。そこで,ここ

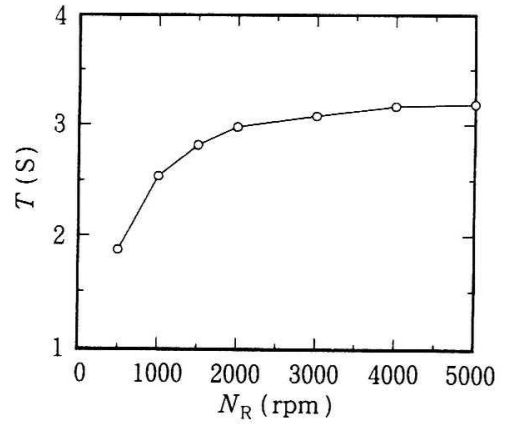

Fig. 4 Time needed for all powder material to go through the gap between vessel and rotor against the revolution of rotor

では複合粒子の評価を，SEMによる複合粒子表面観 察と，その断面構造観察により行った。なお，断面構 造の観察においては, 粒子をエポキシ樹脂中に包埋 後, 切断, 研磨することにより断面を切り出し, その 構造を SEM 並びに EDSにより観察した。

\section{3. 結果亡考察}

\section{1 複合化装置の基本特性評価結果}

まず, 容器を 9 秒間で半回転の条件に設定し, 容器 に投入したガラスビーズ $145.5 \mathrm{~g}$ が供給部からロー ターと容器内壁の間隙部を通過するのに要する時間 $T$ を求め, ローター回転数 $N_{\mathrm{R}}$ との関係を調べた。そ の結果を Fig. 4 に示す。図より, 本実験条件では, ローター回転数の増加とともにわずかながら粉体の通 過時間は増加する傾向にあることが分かる。これは, ローター回転数が増加するほど, 粉体は通過方向とは 逆方向への運動を加速されるためと思われる。

次にFig. 5 は, 一例としてローター回転数が 2,000 $\mathrm{rpm}$ で容器半回転の積算回数 $N$ が 300 の場合に得ら れる複合粒子表面の SEM 観察を行ったものである。 図より，核粒子表面に微粒子の二酸化チタンが比較的 均質に固定化されている様子が観察される。これらの 結果より, 本装置が粒子表面へ微粒子を複合化させる 機能を有していることが分かる。

さらにFig. 6は，複合化過程を定量化するために， 

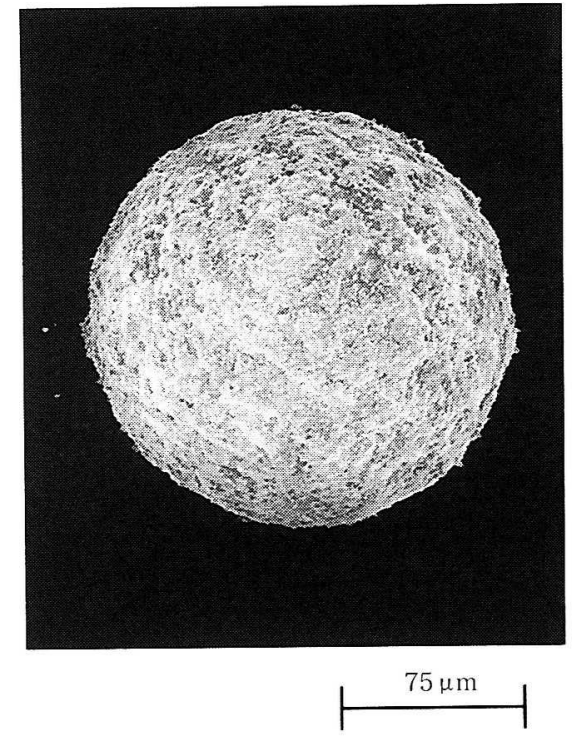

Fig. $5 \mathrm{SEM}$ photograph of glass beads $/ \mathrm{TiO}_{2}$ composite particles $\left(N_{\mathrm{R}}=2000 \mathrm{rpm}\right.$, $N=300$ )

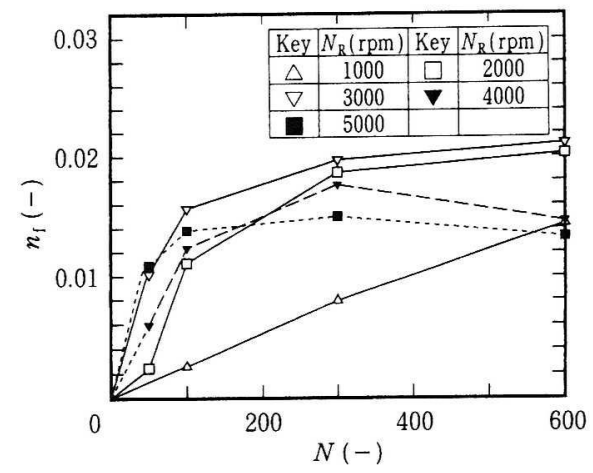

Fig. 6 Change of the mass fraction of fine particles fixed onto core particle surface with cumulative half rotation number of vessel

核粒子表面への微粒子付着率 $n_{\mathrm{f}}$ 之容器半回転の積算 回数 $N$ との関係を生データとして整理した結果であ る。Fig. 4 から明らかなように，今回の実験におい て, 粉体が実際に複合化処理をローターと容器内壁間 にて受けるのは，供給部の半回転当たり 3 秒程度であ ることが分かる。そこで, 実際の複合化処理時間を Fig. 4 に示す粉体通過時間 $T$ と, 供給部の半回転積 算回数 $N$ の積として算出し, 処理粉体の付着率 $n_{\mathrm{f}}$ と の関係で整理すると Fig. 7 となる。図より，ローター 回転数と処理時間が複合化に及ぼす影響を考察してみ ると、ローター回転数が $3,000 \mathrm{rpm}$ までは核粒子表面

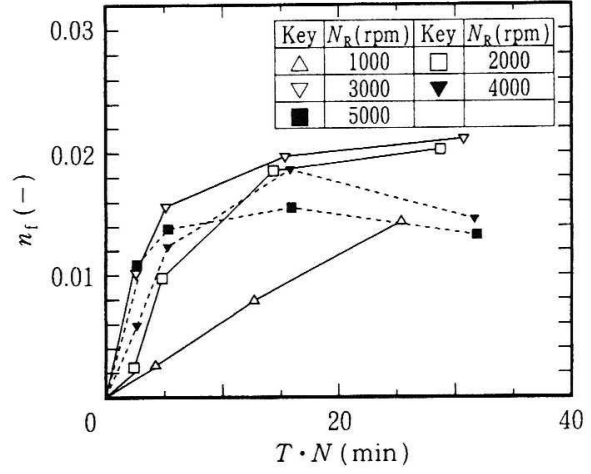

Fig. 7 Change of the mass fraction of fine particles fixed onto core particle surface with estimated processing time

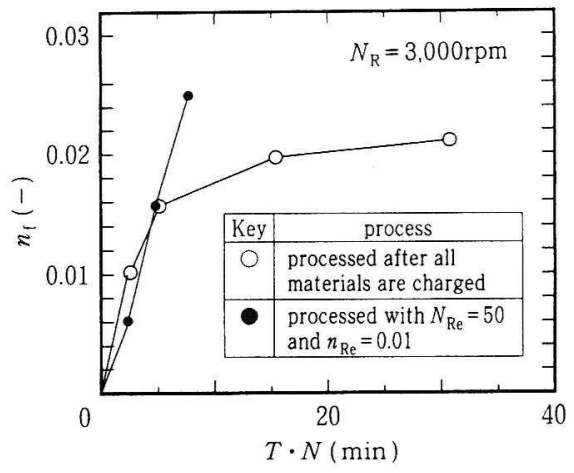

Fig. 8 Effect of feeding method of fine particles on the composite process

への微粒子付着率は処理時間とともに増加するもの の, 回転数が $4,000 \mathrm{rpm}$ になるとある処理時間から微 粒子付着率が減少する傾向が認められる。これらの複 合化過程は, Fig. 1 (a) に示す従来の装置による複合 化過程と定性的には同じであっだ”。さらに、ロー 夕一回転数 4,000 rpm 以上で生じる現象も, 既に報告 しているように核粒子表面からの微粒子の剥離現象で あるものと考えられる7”。た，本結果を先の Fig. 6 上比較すると, 実際の粒子複合化は, 比較的短時間に て進むことが分かる。このことは, ローターと容器内 壁間のクリヤランスへの粉体の供給機構などをさらに 改良することにより，処理時間の一層の短縮と微粒子 付着率の向上が可能であることを示唆している。

次に, 容器半回転回数 50 回毎に微粒子を $1 \mathrm{mass} \%$ ずつ添加した場合の複合化実験結果を，Fig. 8 に示 す。ここでは,一例としてローター回転数は 3,000 $\mathrm{rpm}$, 繰り返し数は 3 回とした。また比較のため に，一度に全量の微粒子を添加して処理した場合の結 


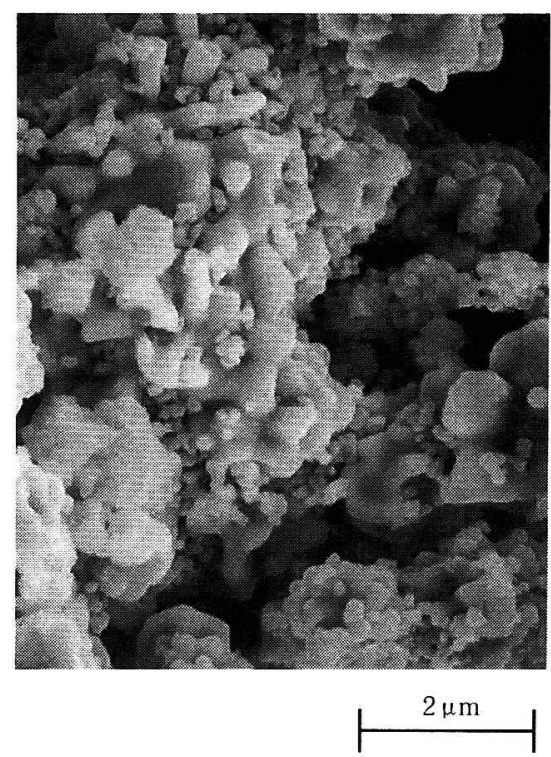

Fig. 9 Filament shaped $\mathrm{Ni}$ particles covered with fine $\mathrm{CoO}$ particles

果（Fig. 7）もあわせて示した。図より，この複合化 装置においても，従来タイプ (Fig. 1 (a)) と同様 ${ }^{8)}$ に，微粒子を繰り返し添加処理することによって，一 度に全量添加した場合に比へて最終付着率を向上可能 なことが分かる。このことは，本装置の持つ機能性を さらに高めるものとして期待される。

以上より，今回試作した複合化装置における基本的 な複合化特性を明らかにするとともに, 微粒子の繰り 返し添加によって, 付着率向上が可能であることを, 実験的に明らかにした。

\section{2 燃料電池電極用複合微粒子の作製結果}

上記複合化実験結果を基に，実際に燃料電池電極合 成の出発原料に用いられる複合微粒子を作製してみ た。まず，Fig. 3に示すフィラメント状の Ni 粒子表 面に $\mathrm{COO}$ 微粒子を複合化した結果について説明す る。ここでの複合化処理は, 微粒子の核粒子表面から の剥離を避けるためにローター回転数 3,500 r pm によ って行い,さらに, $\mathrm{CoO}$ 微粒子は添加率 0.01 にて 5 回繰り返し処理を行った。複合化処理品のSEM 観察 結果の一例を Fig. 9 に示す。図より，ここではフィラ メント状の形状を保った状態にて, Ni 粒子表面に $\mathrm{CoO}$ 微粒子が固定化されている様子が観察される。 この場合の複合化メカニズムの解析には, 今後さらに ローター回転数などの処理条件を变えた系統的検討 が必要であるが，その一つの原因として，ローター と容器内壁間で繰り返し行われる複合化処理の時間間

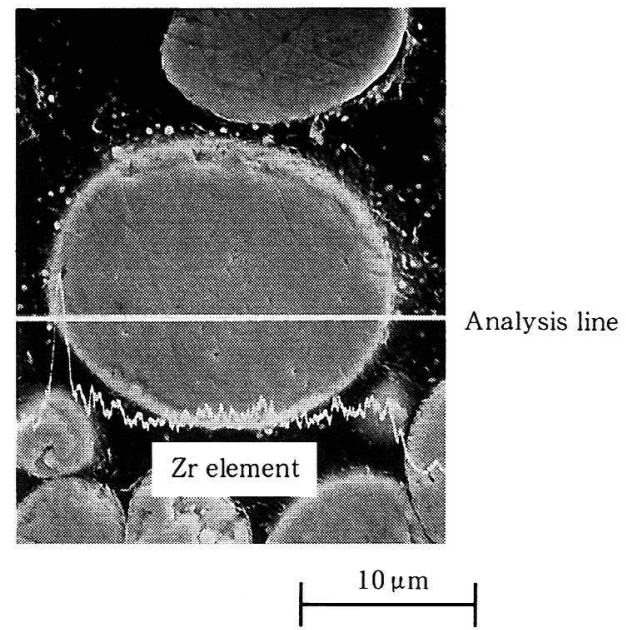

Fig. 10 Cross section of sphere $\mathrm{NiO}$ particles covered with fine YSZ particles

隔が, 通常のバッチ式混合機に比べて比較的長い点 が挙げられる。すなわち, Fig. 1（b）に示す構造にお いては，粒子が複合化時に一瞬高温状態(10)にさらさ れても, その後の容器への移動に伴う十分な緩和時間 により，その変形を回避できるためとも考察される。 この点については, 今後複合化時に粒子に作用する力 やその接触頻度, さらには粒子表面に発生する温度の 計算などの系統的検討を通じて明らかにする予定であ る。

一方，Fig. 10 には，SOFCのカソード材料として 注目されている Ni 球状粒子表面に YSZ 微粒子を複 合化処理したものの断面構造を観察した結果を示す。 ここでも，YSSZ 粒子を $\mathrm{NiO}$ 粉体中に添加率 0.05 ずつ 3 回繰り返し処理した場合の結果を示したが, $\mathrm{NiO}$ 粒子表面に $\mathrm{Zr}$ 成分からなる比較的均質な層が観察さ れる。このことは，YSZ粒子が $\mathrm{Ni}$ 粒子表面に均質に 被覆されていることを示している。

以上より，今回試作した複合化装置によって，燃料 電池用電極材料の原料として必要なフィラメント状の $\mathrm{Ni}$ 粒子に $\mathrm{CoO}$ 微粒子を複合化可能であること, さら には球状 Ni 粒子表面に YSZ 微粒子を複合化可能で あることを明らかにした。今後は, 装置の改良をさら に進めることにより, 容器サイズ・形状や粉体処理量 の最適化の検討などを行い, 大量処理用の装置として 開発する予定である。さらに，実際に得られた複合粒 子を用いて燃料電池電極としての性能を検討し, 高品 質の電極用粉体を低コストで製造するための粒子複合 化技術の確立を進めていく予定である。 


\section{4. 結 言}

1 ) 処理容器の構造と運動に特長を持たせた新しい機 械的粒子複合化装置を試作し, 粒子表面への微粒子 複合化が可能であることを明らかにした。

2 ) 複合化過程は, ロータ一回転数之処理時間の影響 を受け, 回転数が高く処理時間が長いほど核粒子に 強く固定化される微粒子の付着率は增大した。しか し，ある回転数以上では，処理中に一度増加した微
粒子付着率の減少が見られた。

3 ) 微粒子の繰り返し微量添加や粉体の複合化領域へ の供給方法の検討により, 粒子表面への微粒子付着 率の向上が期待できることを示した。

4 ）本装置によって, フィラメント状の $\mathrm{Ni}$ 粒子表面 に $\mathrm{CoO}$ 微粒子を固定化できるなど, 燃料電池電極 材料の合成に必要な複合微粒子を作製可能であるこ とを示した。

\section{Nomenclature}

$d_{\mathrm{c}}:$ diameter of core particle $(\mu \mathrm{m})$

$d_{\mathrm{f}}$ : diameter of fine particle $(\mu \mathrm{m})$

$l$ : minimum length between rotor and vessel $(\mathrm{mm})$

$N$ : cumulative half rotation number of vessel (-)

$N_{\mathrm{Re}}$ : repeated number of cumulative half rotation of vessel

$N_{\mathrm{R}}$ : revolution of rotor

$n_{\mathrm{f}}$ : mass fraction of fine particles fixed onto the surface of core particles $(\mathrm{rpm})$

$(-)$
$n_{\mathrm{Re}}$ : mass fraction of fine particles added repeatedly to the powder material (-)

$T$ : time needed for all powder material to go through the gap between vessel and rotor ( $\mathrm{s}$ )

$t \quad$ : processing time $(\mathrm{min})$ $\rho_{\mathrm{c}}:$ true density of core particle $\quad\left(\mathrm{kg} / \mathrm{m}^{3}\right)$ $\rho_{\mathrm{f}}:$ true density of fine particle $\quad\left(\mathrm{kg} / \mathrm{m}^{3}\right)$ $w_{1}, w_{2}, w_{3}$ : dimensions of vessel (mm)

\section{Reference}

1) Koishi, M., : "Biryushi Sekkei”, Kogyo Chousakai, Tokyo, Japan (1987)

2 ) Wada, M., H. Yoshinaga, O. Kajita, T. Sakai, H. Miyamura, N. Kuriyama and I. Uehara: "Preparation of Copper-Hydrogen Storage Alloy Composites and their Discharge Capacity", J. Soc. Powder and Powder Metallurgy, 40, 1013-1017 (1993)

3 ) Naito, M., M. Yoshikawa, T. Tanaka and A. Kondo: "Analysis of the Powder Composite Process by a Mechanical Method", J. Soc. Powder Technol., Japan, 29, 434-439 (1992)

4 ) Naito, M., A. Kondo and T. Yokoyama : "Applications of Comminution Techniques for the Surface Modification of Powder Materials", ISIJ International, 33, 915-924 (1993)

5 ) Shinohara, K., K. Takayasiki, M. Otani and T. Uchiyama : "Particle Coating Mechanism of Fine Particles by a High-Speed Gas Impact : Wall Effects", Kagaku Kogaku Ronbunshu, 22, 356-364 (1996)

6 ) Satoh, M., T. Yoshida, K. Miyanami and Y. Okudaira : "Evaluation of the Performance of a High-Speed
Elliptical-Rotor-Type Powder Mixer”, J. Soc. Powder Technol., Japan, 31, 789-794 (1994)

7 ) Naito, M., T. Hotta, S. Asahi and T. Tanimoto : "Deposition of Fine Particles on Surface of Core Particles by High-Speed Elliptical-Rotor-Type Mixer", Kagaku Kogaku Ronbunshu, 24, 52-56 (1998)

8 ) Naito, M., T. Hotta, S. Asahi, T. Tanimoto and S. Endoh: "Effect of Processing Conditions on Particle Composite Process by a High-Speed Elliptical-RotorType Mixer", Kagaku Kogaku Ronbunshu, 24, 99-103 (1998)

9 ) Fukui, T., H. Okawa, T. Hotta, M. Naito and T. Yokoyama : "Synthesis of $\mathrm{CoO} / \mathrm{Ni}$ Composite Powders for Molten Carbonate Fuel Cells”, J. Am. Ceram. Soc., 84, 233-235 (2001)

10) Nogi, K., M. Naito, A. Kondo, A Nakahira, K. Niihara and T. Yokoyama: "New Method for Elucidation of Temperature at the Interface between Particles under Mechanical Stirring", J. Soc. Powder and Powder Metallurgy, 43, 396-401 (1996) 